\title{
Polymorphisms in the GHRL gene and their associations with traits of economic interest in beef cattle
}

\author{
C.U. Braz', G.M.F. Camargo', D.F. Cardoso', F.M.M. Gil'1, P.D.S. Fonseca', \\ J.N.S.G. Cyrillo ${ }^{2}$, M.E.Z. Mercadante ${ }^{2}$, H.N. Oliveira ${ }^{1}$ and H. Tonhati ${ }^{1}$ \\ ${ }^{1}$ Faculdade de Ciências Agrárias e Veterinárias, Departamento de Zootecnia, \\ Universidade Estadual Paulista, Jaboticabal, SP, Brasil \\ ${ }^{2}$ Centro APTA Bovinos de Corte, Sertãozinho, SP, Brasil \\ Corresponding author: C.U. Braz \\ E-mail: camila_urbano@yahoo.com.br
}

Genet. Mol. Res. 14 (4): 18188-18197 (2015)

Received July 20, 2015

Accepted September 24, 2015

Published December 23, 2015

DOI http://dx.doi.org/10.4238/2015.December.23.6

ABSTRACT. The hormone ghrelin is produced in the stomach wall, has an orexigenic function, stimulates growth hormone secretion, and affects the energy balance of the animal. Therefore, the ghrelin gene (GHRL) is considered to be a good candidate marker for the identification of traits of great economic importance in cattle, such as those associated with feed intake, growth, and carcass quality. The use of molecular genetic markers associated with such traits permits the earlier and more accurate identification of superior animals, thus reducing the interval between generations, and increasing the genetic gain. Six SNPs were found in the GHRL gene, located in intron 3, intron 4, and exon 5. The positions of the SNPs on the gene and the substitutions were: g.2184A $>$ G, g.2347T $>C$, g.4469T $>C$, g.4548A $>$ G, g.4663T $>C$, and g.4729T $>C$ (GenBank accession No. JX565585). After analysis of linkage disequilibrium, association tests were performed between four SNPs with the traits year weight for males, yearling weight for females, dry matter intake, loin eye area, and rump fat thickness $(P \leq 0.05)$. Therefore, GHRL is an important candidate gene that 
may be used to identify genetic variations that influence traits of economic importance in beef cattle.

Key words: GHRL; Molecular markers; Nellore; SNP

\section{INTRODUCTION}

Selecting for high feed efficiency in animals can raise profitability and reduce the environmental impact of beef cattle breeding (Gomes et al., 2012). Feed efficiency traits, such as residual feed intake and dry matter intake, in Nellore cattle show heritability estimates of 0.30 and 0.41 , respectively (Del Claro et al., 2012). In turn, the heritability estimates for meat quality traits, such as back-fat thickness and loin eye area, are 0.24 and 0.33 , respectively (Meirelles et al., 2010). The heritability levels for these traits are medium-to-high, but they are very difficult to measure because of the need for specific equipment and/or intensive labor to obtain the individual intake.

The use of molecular markers in animal breeding can increase the accuracy of prediction, reduce the interval between generations, and thus increase the genetic gain for traits that are difficult to measure and/or are measured late in life.

The ghrelin gene (GHRL) is a candidate marker because the hormone encoded by this gene induces hunger and is, therefore, related to feed intake (Gil et al., 2013). The hypothalamus is a component of the nervous system that is involved in the control of food consumption and body weight. The hypothalamus receives signals in the form of hormones such as ghrelin, which stimulate hunger (St-Pierre et al., 2003).

Ghrelin is a gastrointestinal hormone that was first identified in the stomach of rats (Kojima et al., 1999). It is a peptide composed of 28 amino acids with an octanoic modification in its hydroxyl group on serine-3, which is essential for its effect on growth hormone $(G H)$ release (Bednarek et al., 2000). It was first isolated from the oxyntic mucosa of the stomach and is predominantly produced by cells of the gastrointestinal tract. Ghrelin is also produced in small quantities in the central nervous system, kidneys, placenta, and heart (Kojima et al., 1999).

The GHRL gene in cattle is composed of five exons and four introns, with exons 1, 2, 3, 4, and 5 having lengths of $21,134,114,109$, and $154 \mathrm{bp}$, respectively, while the coding region contains exons 2, 3, 4 and 5 (partially) (Colinet et al., 2009). The GHRL gene is located on chromosome 22 in cattle (Wajnrajch et al., 2000) and is a candidate gene for the identification of molecular markers, because it induces food ingestion, secretion of $\mathrm{GH}$, adiposity, and susceptibility to obesity (Sun et al., 2011). In the regulation of energy balance, ghrelin increases feed intake and reduces energy expenditure (Hinney et al., 2002).

Ukkola and Pöykkö (2002) found associations between ghrelin and reduced fat oxidation, increased feed intake, adiposity, and body weight. According to Martinelli et al. (2008), ghrelin stimulates the secretion of $\mathrm{GH}$, such that changes in gene expression are associated with variations in cattle weight at different ages. Both Kojima et al. (1999) and Date et al. (2000) reported that ghrelin influences important activities, including stimulation of lactotroph and corticotroph secretion, and influencing the pituitary-gonadal axis, as well as having orexigenic activity (stimulating appetite) and controlling energy expenditure.

Polymorphisms in GHRL were detected and associated with traits of economic importance in different species of animals (Kim et al., 2004; Fang et al., 2007; Sherman et al., 2007; Sun et al., 2011; Wojtysiak and Kaczor, 2011; Zhang et al., 2012; Gil et al., 2013). 
Therefore, the aim of this study was to investigate the existence of polymorphisms in regions of the GHRL gene and to evaluate the association of these polymorphisms with feed efficiency, growth, and meat quality traits of Nellore cattle.

\section{MATERIAL AND METHODS}

\section{Animals}

A total of 231 animals (110 females and 121 males) born in 2009 and 2010 were used, which belonged to Centro APTA Bovinos de Corte (IZ), located in the municipality of Sertãozinho, São Paulo state, Brazil. Animals were of the Traditional Nellore selection line, which has been selected for higher yearling weight since 1981. Details of the breeding program are described by Ayres et al. (2010). The males were participants in the station's weight-gain test program, as described by Razook et al. (1997) and animals of both sexes were included in the residual feed intake (RFI) analysis performed in 2010 and 2011, which began after weaning. This study was conducted under animal care conditions as established by the São Paulo State Constitution, according to law number 11,977 .

The animals were raised in an intensive system. They were kept in individual stalls and underwent an adaptation period of 28 days, after which the feed consumption period varied from 72 to 112 days, during which they received a predetermined quantity of feed composed of Brachiaria hay, ground corn, and cottonseed meal. The ration was offered twice during the day (8 am and $3 \mathrm{pm})$. Each day, the amount of ration not ingested for each animal was weighed, registered, and adjusted in order to keep an amount between $5-10 \%$ of the total ration. To performance the analyses, samples of ration not ingested were collected twice a week in a period of 28 days (total of eight samples) per animal. The dry matter consumption of each animal was determined as the difference between the ration offered and that not ingested.

\section{Traits studied}

The traits of economic interest studied were year weight (males), standardized to 378 days of age (W378), yearling weight (females), standardized to 550 days of age (W550), rump height of males (RHM), rump height of females (RHF), dry matter intake (DMI), and RFI. The loin eye area (LMA), back fat thickness (BF), and rump fat thickness (RF) were measured at 12 and 18 months of age (LMA12, LMA18, BF12, BF18, RF12, and RF18, respectively).

The rump height of all animals was measured with a tape measure, by taking the distance in centimeters from the ground to the tip of the sacrum bone. The DMI was determined by the mean consumption during the RFI test period (kg/day). The RFI, in $\mathrm{kgMD} /$ day, was calculated as the difference between the DMI observed during the study period and that predicted by a multiple regression equation, considering the daily weight gain (DWG) and metabolic weight $\left(\mathrm{LW}^{0.75}\right)$ as covariables.

The ultrasound technique was used to measure carcass traits, namely the LMA and BF, which were both measured between the 12th and 13th ribs in the Longissimus dorsi muscle, and the RF, which was measured between the Gluteos medius and Biceps femoris muscles, located between the ilium and ischium, according to the method described by Herring et al. (1994). Ultrasounds were performed when the animals were between 329 and 408 days of age (12 month reading) and between 503 and 600 days of age (18 month reading). 


\section{Genotyping and sequencing}

DNA was extracted from hair follicle samples using the phenolchloroform-isoamyl alcohol method. Three primer pairs were designed for the GHRL gene (GenBank accession No. AM691749.1), as shown in Table 1. The primers were obtained using the Primer3 software, available at http://frodo.wi.mit.edu/primer3, and the quality was verified using the site http://idtdna. com/calc/analyzer.

The amplification reactions consisted of a final volume of $25 \mu \mathrm{L}$, containing $2 \mu \mathrm{L}$ DNA (100 ng), $1.5 \mu \mathrm{L}$ each primer (15 pM), $12.5 \mu \mathrm{L}$ GoTaq Colorless Master Mix 1X Taq DNA polymerase, and $7.5 \mu \mathrm{L}$ nuclease free water. The following program was employed: denaturation at $95^{\circ} \mathrm{C}$ for 5 min, followed by 32 cycles of denaturation at $95^{\circ} \mathrm{C}$ for $1 \mathrm{~min}$, annealing at a temperature specific to each primer pair for $1 \mathrm{~min}$, extension at $72^{\circ} \mathrm{C}$ for $1 \mathrm{~min}$, and final extension at $72^{\circ} \mathrm{C}$ for $5 \mathrm{~min}$.

The PCR products were sequenced for the forward and reverse primers by the dideoxyribonucleoside triphosphate chain termination method (ddNTP). To analyze and identify polymorphisms, all sequences obtained were visualized with the CodonCode Aligner program, available at http://www.codoncode.com/aligner/download.htm.

Table 1. Sequence, fragment lengths, and melting temperature of the primer pairs used in PCR assays.

\begin{tabular}{lllcc}
\hline NP & Region of the amplified fragment & Sequence & Fragment length (bp) & Melting temperature $\left({ }^{\circ} \mathrm{C}\right)$ \\
\hline E3 & Exon 3 & F: 5'-AGCACCTCCTCTTTCCTGCAGAG-3' & 282 & 64.3 \\
& & R: 5'-TTGGCCTGTTGATGGCAGAGAC-3' & 409 & 63.4 \\
I3 & Part of intron 3 & F: 5'-TGCATTGCCAGGTGGTTCTCTAC-3' & \\
& & R: 5'-AGAATCTGCAGGCCGCCGTGAAGT-3' & 437 & 63.3 \\
E5 & Part of intron 4 and exon 5 & F: 5'-GGGAGGAGAGCAGACACAGT-3' & \\
& & R: 5'-TGACCACAGACCAGGAATTG-3' & \\
\hline
\end{tabular}

$N P=$ name of the primer, $F=$ forward, $R=$ reverse.

\section{Analysis of linkage disequilibrium}

Linkage disequilibrium $\left(\mathrm{r}^{2}\right)$ was estimated using the Plink computational program (available at http://pngu.mgh.harvard.edu/ purcell/plink/) to determine which SNPs were inherited together. Considering two loci with two alleles per locus (A1/A2 and B1/B2), the following formula applies:

$$
r^{2}=D^{2} /[\text { freq }(A 1) \times \text { freq }(A 2) \times \text { freq }(B 1) \times \text { freq }(B 2)] \quad \text { Equation } 1
$$

(Hill and Robertson, 1966) where:

$$
D=\operatorname{freq}\left(A 1_{-} B 1\right) \times \operatorname{freq}\left(A 2_{-} B 2\right)-\operatorname{freq}\left(A 1_{-} B 2\right) \times \operatorname{freq}\left(A 2_{-} B 1\right)
$$

(Hill, 1981). The program compares the observed and expected haplotype frequencies of the haplotypes in order to determine whether they are in linkage disequilibrium (LD). If haplotypes are in LD, they may have the same statistical association with the trait.

\section{Statistical analysis}

Associations between the markers and phenotypic records were analyzed using generalized linear models, available in the PROC MIXED of the SAS 9.1.3 statistical package 
(SAS Institute, 2000). The effects of the polymorphisms identified for the GHRL gene on the traits investigated were estimated by applying the following statistical model:

$$
Y_{i j k}=\mu+G C_{i}+S_{j}+T_{k}+\alpha_{1}\left(I_{i j k}-\bar{I}\right)+\beta_{1}\left(L_{i j k}-\bar{L}\right)+e_{i j k} \quad \text { Equation } 3
$$

where: $Y_{i j k}=$ dependent variable of the $i j k^{\text {th }}$ animal; $\mu=$ average of the each trait in the population; $\mathrm{GC}_{i}=$ fixed effect associated with the $i^{\text {th }}$ contemporary group; $\mathrm{S}_{j}=$ fixed effect associated with the $j^{\text {th }}$ polymorphism of the GHRL gene; $T_{k}=$ random effect associated with the $k^{\text {th }}$ sire; $\alpha_{1}=$ linear regression coefficient of trait $Y_{i j k}$ in relation to cow age; $\beta_{1}=$ linear regression coefficient of trait $Y_{i j k}$ in relation to animal age at the time of measurement; $I_{\mathrm{ijk}}=$ cow age; $\bar{I}=$ means age of cows; $L_{\mathrm{ijk}}=$ animal age at measurement; $\bar{L}=$ mean age of animals at measurement; and $e_{i j k}=$ residual random error associated with the $\mathrm{ijk}^{\text {th }}$ observation.

The contemporary groups were formed by birth year (2009 and 2010), birth month $(9,10$, 11 , and 12), and sex.

\section{RESULTS}

Six SNPs were identified in the regions analyzed, two of which were in the intron 3 region of the GHRL gene (g.2184A>G and g.2347T>C). In the region covered by the E5 primer pair, four polymorphisms for the partial region of intron 4 and exon 5 of the GHRL gene were identified. The SNPs g.4469T $>C$ and g.4548A $>\mathrm{G}$ are located in intron 4, while g.4663T $>C$ and g.4729T $>C$ are located in exon 5 in the 3 'UTR region (Table 2). All sequences and polymorphisms found were submitted to NCBI database (http://www.ncbi.nlm.nih.gov) under the accession No. JX565585. These are the first polymorphisms described for the GHRL gene in Nellore cattle.

\begin{tabular}{|c|c|c|c|}
\hline Identification of the SNPs & Primer & Region & SNP \\
\hline g.2184 & 13 & intron 3 & $A>G$ \\
\hline g.2347 & 13 & intron 3 & $\mathrm{~T}>\mathrm{C}$ \\
\hline g.4469 & E5 & intron 4 & $\mathrm{~T}>\mathrm{C}$ \\
\hline g. 4548 & E5 & intron 4 & $A>G$ \\
\hline g.4663 & E5 & exon 5 (3'UTR) & $\mathrm{T}>\mathrm{C}$ \\
\hline g.4729 & E5 & exon 5 (3'UTR) & $\mathrm{T}>\mathrm{C}$ \\
\hline
\end{tabular}

Allelic and genotypic frequencies were calculated by counting and were tested for HardyWeinberg equilibrium at 5\% (Table 3). The SNPs g.2184A $>$ G, g.2347T >C, g.4469T >C, and g.4663T >C were in Hardy-Weinberg equilibrium, this indicates that these loci were not affected by selection.

Table 3 shows that three possible genotypes were found for each SNP, except for g.2347T $>$ C , because this SNP was not identified in animals with the CC genotype.

LD was estimated to determine which polymorphisms frequently segregated together. According to Ardlie et al. (2002), if the $r^{2}$ value is higher than 0.33 , then LD is strong. In the present study, the $r^{2}$ values varied from 0 to 0.955 (Table 4). The SNPs g.2347T>C, g.4548A>G, and g.4729T $>C$ presented $r^{2}$ values lower than 0.33 with all other SNP, and between each other, varying from 0 to 0.286 , meaning they are in LD and are inherited separately. However, SNPs g.2184A>G, g.4469T >C and g.4463T >C presented $r^{2}$ values higher than 0.33 , indicating that these SNPs are in LD and are more frequently inherited together. Thus, one SNP among them (g.4663T $>C$ ) was used 
for the association test. Therefore, the SNPs g.2347T>C, g.4548A>G, g.4729T>C, and g.4663T>C were used to analyze the association with the phenotype values of the traits of interest.

\begin{tabular}{|c|c|c|c|c|c|c|}
\hline \multirow[t]{2}{*}{ SNP } & \multicolumn{2}{|c|}{ Allelic frequency } & \multicolumn{3}{|c|}{ Genotypic frequency } & \multirow{2}{*}{$\begin{array}{c}\text { Hardy-Weinberg } \\
\text { equilibrium (Chi-squared) }\end{array}$} \\
\hline & A & G & AA & AG & GG & \\
\hline g. $2184 A>G$ & 0.39 & 0.61 & 0.13 & 0.52 & 0.35 & yes \\
\hline \multirow[t]{2}{*}{ g. $4548 A>G$} & 0.31 & 0.69 & 0.06 & 0.49 & 0.45 & no \\
\hline & C & $\mathrm{T}$ & $\mathrm{CC}$ & TC & TT & \\
\hline g. $2347 \mathrm{~T}>\mathrm{C}$ & 0.05 & 0.95 & 0.00 & 0.09 & 0.91 & yes \\
\hline g.4469T $>\mathrm{C}$ & 0.60 & 0.40 & 0.33 & 0.54 & 0.13 & yes \\
\hline g. $4663 \mathrm{~T}>\mathrm{C}$ & 0.61 & 0.39 & 0.35 & 0.53 & 0.12 & yes \\
\hline g. $4729 \mathrm{~T}>\mathrm{C}$ & 0.46 & 0.54 & 0.03 & 0.86 & 0.11 & no \\
\hline
\end{tabular}

${ }^{*}$ The Hardy-Weinberg equilibrium was tested at $5 \%$ (Chi-squared values $>3.14=$ disequilibrium).

Table 4. Estimated pairwise linkage disequilibrium $\left(r^{2}\right)$ values for six SNPs found on the GHRL gene in Nellore cattle.

\begin{tabular}{lccccc}
\hline SNPs & g.2184 & g.2347 & g.4469 & g.4548 & g.4663 \\
\hline g.2184A>G & - & - & - & - & - \\
g.2347T>C & 0.000 & - & - & - & - \\
g.4469T>C & 0.954 & 0.001 & - & - & - \\
g.4548A $>$ G & 0.286 & 0.019 & 0.274 & - & - \\
g.4663T>C & 0.945 & 0.000 & 0.955 & 0.277 & - \\
g.4729T>C & 0.000 & 0.001 & 0.002 & 0.000 & - \\
\hline
\end{tabular}

These SNPs were associated with some traits (Table 5). The SNP g.2347T>C was associated with DMI, LMA18, and W378 ( $\mathrm{P} \leq 0.05$ ); SNP g.4663T $>C$ was associated with RF12, BF12, W550, and RHM ( $P \leq 0.05)$; and g.4548A $>G$ was associated with W550 and RHF $(P \leq 0.05)$. The SNP g.4729T>C was not found to have significant differences among the genotypes $(P \geq$ 0.05), indicating that this SNP does not influence these traits.

For SNP g.2347T>C, the TT genotype presented the highest average for the W378, DMI, and LMA18 traits (Table 6). For SNP g.4548A>G, there were no significant differences between the $A A$ and $A G$ genotypes, or between the $A A$ and $G G$ genotypes, for both traits (W550 and RHF). However, the GG genotype presented a higher average compared with the AG genotype. For the SNP g.4663T>C, the genotype that presented the highest average for the W550 trait was TT. For the RHF trait, there were no significant differences between the TT and CT genotypes, but a higher average was presented for the CC genotype. For the RF12 trait, there were no significant differences between the CC and TT genotypes, but differences with the CT genotype were found, which had a lower average than the CC and TT genotypes. For the BF12 trait, there were no significant differences between the CC and CT genotypes, or between the CC and TT genotypes; however, the TT genotype presented a higher average compared with the CT genotype. 
Table 5. P values obtained for effects of the genotypes on growth, feed efficiency, and carcass traits.

\begin{tabular}{|c|c|c|c|c|c|c|c|c|c|c|c|c|}
\hline \multirow[t]{2}{*}{ SNPs } & \multicolumn{4}{|c|}{ Growth traits ${ }^{1}$} & \multicolumn{2}{|c|}{ Feed efficiency traits ${ }^{1}$} & \multicolumn{6}{|c|}{ Carcass traits ${ }^{1}$} \\
\hline & W550 & W378 & RHF & RHM & DMI & $\mathrm{RFI}$ & LMA12 & BF12 & RF12 & LMA18 & BF18 & RF18 \\
\hline g. $2347 \mathrm{~T}>\mathrm{C}$ & 0.40 & $0.01^{*}$ & 0.16 & 0.66 & $0.02^{*}$ & 0.56 & 0.43 & 0.68 & 0.36 & $0.01^{*}$ & 0.15 & 0.22 \\
\hline g. $4548 A>G$ & $0.03^{*}$ & 0.25 & $0.05^{*}$ & 0.74 & 0.37 & 0.49 & 0.63 & 0.79 & 0.84 & 0.80 & 0.91 & 0.62 \\
\hline g. $4663 \mathrm{~T}>\mathrm{C}$ & $0.05^{*}$ & 0.27 & $0.05^{*}$ & 0.87 & 0.50 & 0.70 & 0.07 & $0.05^{\star}$ & $0.01^{*}$ & 0.07 & 0.21 & 0.11 \\
\hline g. $4729 \mathrm{~T}>\mathrm{C}$ & 0.56 & 0.16 & 0.60 & 0.26 & 0.48 & 0.64 & 0.24 & 0.47 & 0.34 & 0.10 & 0.88 & 0.79 \\
\hline
\end{tabular}

${ }^{1}$ W550 = yearling weight for females, standardized to 550 days of age $(\mathrm{kg}) ; \mathrm{W} 378=$ year weight for male, standardized to 378 days of age $(\mathrm{kg})$; RHF = rump height for females $(\mathrm{cm})$; RHM = rump height for males $(\mathrm{cm})$; DMI = dry matter intake $\left(\mathrm{kg} /\right.$ day); RFI = residual feed intake $(\mathrm{kgMD} /$ day $) ;$ LMA12 = loin eye area $\left(\mathrm{cm}^{2}\right), \mathrm{BF} 12=$ back fat thickness $(\mathrm{mm})$ and RF12 = rump fat thickness $(\mathrm{mm})$, measured at 12 months; LMA18 = loin eye area $\left(\mathrm{cm}^{2}\right)$, BF18 $=$ back fat thickness $(\mathrm{mm})$ and RF18 $=$ rump fat thickness $(\mathrm{mm})$, measured at 18 months. ${ }^{*}$ Means followed by at least one letter are not significantly different (at $5 \%$ ).

Table 6. Means and standard errors for genotypes found for the traits that were associated with the polymorphisms

\begin{tabular}{|c|c|c|c|c|c|c|c|}
\hline Traits $^{1}$ & W550 & W378 & RHF & DMI & BF12 & RF12 & LMA18 \\
\hline \multicolumn{8}{|c|}{ g. $2347 \mathrm{~T}>\mathrm{C}$} \\
\hline CT & $345.98 \pm 14.38$ & $324.25 \pm 9.99^{b}$ & $137.66 \pm 1.55$ & $6.18 \pm 0.17^{b}$ & $1.78 \pm 0.19$ & $4.76 \pm 0.38$ & $50.61 \pm 2.34^{b}$ \\
\hline $\mathrm{TT}$ & $357.72 \pm 5.10$ & $347.27 \pm 7.42^{\mathrm{a}}$ & $139.78 \pm 0.55$ & $6.54 \pm 0.10^{\mathrm{a}}$ & $1.85 \pm 0.06$ & $5.08 \pm 0.17$ & $56.55 \pm 1.11^{\mathrm{a}}$ \\
\hline \multicolumn{8}{|c|}{ g. $4548 A>G$} \\
\hline AA & $351.73 \pm 11.48^{\mathrm{ab}}$ & $351.16 \pm 14.82$ & $139.04 \pm 1.24^{\mathrm{ab}}$ & $6.26 \pm 0.20$ & $1.99 \pm 0.22$ & $5.21 \pm 0.43$ & $57.41 \pm 2.61$ \\
\hline$A G$ & $352.69 \pm 5.37^{b}$ & $347.48 \pm 8.03$ & $139.27 \pm 0.58^{b}$ & $6.53 \pm 0.10$ & $1.86 \pm 0.08$ & $5.05 \pm 0.19$ & $55.94 \pm 1.27$ \\
\hline GG & $366.27 \pm 6.11^{\mathrm{a}}$ & $338.07 \pm 8.03$ & $140.61 \pm 0.66^{a}$ & $6.50 \pm 0.11$ & $1.83 \pm 0.08$ & $5.13 \pm 0.20$ & $56.42 \pm 1.32$ \\
\hline \multicolumn{8}{|c|}{ g. $4663 T>C$} \\
\hline $\mathrm{CC}$ & $351.94 \pm 6.24^{b}$ & $348.92 \pm 8.48$ & $138.80 \pm 0.97^{b}$ & $6.56 \pm 0.11$ & $1.94 \pm 0.10^{\mathrm{ab}}$ & $5.35 \pm 0.22^{\mathrm{a}}$ & $55.76 \pm 1.33$ \\
\hline CT & $357.49 \pm 5.48^{\mathrm{b}}$ & $388.66 \pm 8.48$ & $140.07 \pm 0.54^{a}$ & $6.45 \pm 0.11$ & $1.76 \pm 0.08^{b}$ & $4.84 \pm 0.18^{b}$ & $55.44 \pm 1.27$ \\
\hline TT & $373.95 \pm 8.92^{\mathrm{a}}$ & $337.663 \pm 10.13$ & $140.70 \pm 0.96^{a}$ & $6.56 \pm 015$ & $2.11 \pm 0.15^{\mathrm{a}}$ & $5.59 \pm 0.32^{\mathrm{a}}$ & $59.56 \pm 1.86$ \\
\hline \multicolumn{8}{|c|}{ g. $4729 \mathrm{~T}>\mathrm{C}$} \\
\hline $\mathrm{CC}$ & $361.31 \pm 13.32$ & $400.23 \pm 32.32$ & $140.23 \pm 1.32$ & $6.70 \pm 0.26$ & $2.00 \pm 0.28$ & $5.64 \pm 0.54$ & $52.22 \pm 3.06$ \\
\hline CT & $356.06 \pm 5.27$ & $340.76 \pm 7.48$ & $139.60 \pm 0.57$ & $6.49 \pm 0.10$ & $1.86 \pm 0.07$ & $5.05 \pm 0.16$ & $56.18 \pm 1.14$ \\
\hline TT & $364.89 \pm 9.43$ & $345.96 \pm 11.50$ & $140.44 \pm 1.01$ & $6.62 \pm 0.16$ & $2.02 \pm 0.17$ & $5.39 \pm 0.35$ & $59.19 \pm 2.10$ \\
\hline
\end{tabular}

${ }^{1} \mathrm{~W} 550=$ yearling weight for females, standardized to 550 days of age $(\mathrm{kg}), \mathrm{W} 378=$ year weight for males, standardized to 378 days of age $(\mathrm{kg}), \mathrm{RHF}=$ rump height for females $(\mathrm{cm}), \mathrm{DMI}=$ dry matter intake $(\mathrm{kg} /$ day $), \mathrm{BF} 12=$ back fat thickness $(\mathrm{mm})$ and RF12 = rump fat thickness $(\mathrm{mm})$, measured at 12 months, LMA18 = loin eye area $\left(\mathrm{cm}^{2}\right)$, measured at 18 months.

\section{DISCUSSION}

The SNP g.2347T >C presented a high T allele frequency, which differed from that occurring in the remaining SNPs found. This may be due to genetic drift, since artificial selection involves the selection of a small number of parents, mainly bulls, to form the next generation (Walsh, 1999). As a consequence, the fixation of the $T$ allele may be occurring and causing the $C$ allele to be lost. According to Van Vleck et al. (1987), sampling can cause random changes in gene frequency and may also result in the loss of one of the alleles and of one of the homozygous types.

Sherman et al. (2007) found one SNP in intron 3 of the GHRL gene in Angus, Charolais, and hybrid cattle. This SNP presented a low frequency of the $G$ allele in the population (0.12), which is consistent with the results from the present study. Therefore, the GG genotype was not included in these analyzes.

The associations of these SNPs with body weight and rump height indicate that this gene affects animal growth. Zhang et al. (2012) found that some SNPs within the promoter region of 
the GHRL gene in cattle were associated with ischium width. Fang et al. (2007) observed an association between polymorphism in the GHRL gene, located on exon 1, and the weight of the entire body, and the leg and breast of chickens. These results are consistent with GHRL promoting the release of GH (Kojima et al., 1999; Bednarek et al., 2000; Martinelli et al., 2008). However, when analyzing Chinese cattle, Sun et al. (2011) detected 11 SNPs in the GHRL gene but did not find any significant association between the genotypes and body weight, average daily weight gain, and body size at different ages.

In addition to a role for ghrelin in $\mathrm{GH}$ release, this hormone has also been shown to play important roles in the stimulation of appetite and feeding activity (Jarkovska et al., 2004). This is consistent with the present results, because the SNP g.2347T >C was associated with dry matter intake. Sherman et al. (2007) associated one SNP in the bovine GHRL gene with RFI and conversion traits. Ukkola and Pöykkö, (2002) found associations between ghrelin and the increased feed intake.

The associations of the SNPs found in the present study with carcass merit including LMA, $\mathrm{BF}$, and RF are also consistent with the roles of the GHRL gene. Wojtysiak and Kaczor (2011) demonstrated associations of GHRL polymorphisms with carcass weight, ham weight, loin weight, longissimus muscle area, abdominal fat, and back fat thickness. Sherman et al. (2007) identified an SNP in the GHRL gene that had a small association with carcass merit, including positive effects on meat yield, productivity, and meat quality of beef cattle. In pigs, a polymorphism in the GHRL gene was found to be associated with back fat thickness, marbling, and other carcass traits (Kim et al. 2004). The ghrelin gene induces adiposity and causes susceptibility to obesity (Ukkola and Pöykkö, 2002; Sun et al. 2011).

SNPs that are associated with the traits studied here are located in non-coding DNA regions, that is, they are located in 3'UTR and intronic regions. Among the possible explanations for this fact is that the SNPs might be in LD with other SNPs on the gene that have more accentuated effects on the traits analyzed (Sherman et al. 2007).

Greenwood and Kelsoe (2003) and LeHir et al. (2003) also reported that introns affect the efficiency of transcription, while Nakaya et al. (2007) suggested that many introns produce noncoding RNA and regulate coding genes. Ropka-Molik et al. (2011) reported that polymorphisms in the $5^{\prime}$ and $3^{\prime}$ UTR regions play a role in gene expression by controlling polyadenylation, stability, and location of mRNA.

Therefore, the ghrelin gene is an important candidate for the identification of genetic variations that influence traits of economic importance in beef cattle. Future studies may be conducted to verify the influence of non-coding DNA regions and the influence of the GHRL gene in important economic traits.

\section{Conflicts of interest}

The authors declare no conflict of interest.

\section{ACKNOWLEDGMENTS}

Research supported by Conselho Nacional de Desenvolvimento Científico e Tecnológico (CNPq) and Fundação à Pesquisa do Estado de São Paulo (Fapesp). We are grateful to the Centro APTA Bovinos de Corte for providing the hair samples and the data set used in this study. 


\section{REFERENCES}

Ardlie KG, Kruglyak L and Seielstad M (2002). Patterns of linkage disequilibrium in the human genome. Nat. Rev. Genet. 3: 299-309.

Ayres DR, Souza FR, Mercadante ME, Fonseca LF, et al. (2010). Evaluation of TFAM and FABP4 gene polymorphisms in three lines of Nellore cattle selected for growth. Genet. Mol. Res. 9: 2050-2059.

Bednarek MA, Feighner SD, Pong SS, McKee KK, et al. (2000). Structure-function studies on the new growth hormonereleasing peptide, ghrelin: Minimal sequence of ghrelin necessary for activation of growth hormone secretagogue receptor 1a. J. Med. Chem. 43: 4370-4376.

Colinet FG, Portetelle D and Renaville R (2009). Molecular characterization of the bovine GHRL gene (Short Communication). Archiv. Tierzucht. 52: 79-84.

Date Y, Kojima M, Hosoda H, Sawaguchi A, et al. (2000). Ghrelin, a novel growth hormone-releasing acylated peptide, is synthesized in a distinct endocrine cell type in the gastrointestinal tracts of rats and human. Endocrinology 141: 4255-4261.

Del Claro AC, Mercadante MEZ and Silva JAV (2012). Meta-analise de parâmetros genéticos relacionados ao consumo alimentar residual e a suas características componentes em bovinos. Pesq. Agropec. Bras. 47: 302-310.

Fang M, Nie Q, Luo C, Hang D, et al. (2007). An 8 bp indel in exon 1 of Ghrelin gene associated with chicken growth. Domest. Anim. Endocrinol. 32: 216-225.

Gil FM, de Camargo GM, de Souza FR, Cardoso DF, et al. (2013). Polymorphisms in the ghrelin gene and their associations with milk yield and quality in water buffaloes. J. Dairy Sci. 96: 3326-3331.

Gomes RC, Sainz RD, Silva SL, César MC, et al. (2012). Feedlot performance, feed efficiency reranking, carcass traits, body composition, energy requirements, meat quality and calpain system activity in Nellore steers with low and high residual feed intake. Livest. Sci. 150: 265-273.

Greenwood TA and Kelsoe JR (2003). Promoter and intronic variants affect the transcriptional regulation of the human dopamine transporter gene. Genomics 82: 511-520.

Herring WO, Miller DC, Bertrand JK and Benyshek LL (1994). Evaluation of machine, technician, and interpreter effects on ultrasonic measures of backfat and longissimus muscle area in beef cattle. J. Anim. Sci. 72: 2216-2226.

Hill WG (1981). Estimation of effective population size from data on linkage disequilibrium. Genet. Res. 38: 209-216.

Hill WG and Robertson A (1966). The effect of linkage on limits to artificial selection. Genet. Res. 8: 269-294.

Hinney A, Hoch A, Geller F, Schäfer H, et al. (2002). Ghrelin gene: identification of missense variants and a frame shift mutation in extremely obese children and adolescents and healthy normal weight students. J. Clin. Endocrinol. Metab. 87: 2716-2724.

Jarkovska Z, Krsek M, Rosicka M and Marek J (2004). Endocrine and metabolic activities of a recently isolated peptide hormone ghrelin, an endogenous ligand of the growth hormone secretagogue receptor. Endocr. Regul. 38: 80-86.

Kim KS, Thomsen H, Bastiaansen J, Nguyen NT, et al. (2004). Investigation of obesity candidate genes on porcine fat deposition quantitative trait loci regions. Obes. Res. 12: 1981-1994.

Kojima M, Hosoda H, Date Y, Nakazato M, et al. (1999). Ghrelin is a growth-hormone-releasing acylated peptide from stomach. Nature 402: 656-660.

LeHir H, Nott A and Moore MJ (2003). How introns influence and enhance eukaryotic gene expression. Trends Biochem. Sci. 28: 215-220.

Martinelli CE Jr, Custódio RJ and Aguiar-Oliveira MH (2008). Physiology of the GH-IGF axis. Arq. Bras. Endocrinol. Metabol. 52: 717-725.

Meirelles SL, Alencar MM, Oliveira HN and Regitano LCA (2010). Efeitos de ambiente e estimativas de parâmetros genéticos para características de carcaça em bovinos da raça Canchim criados em pastagem. Rev. Bras. Zootec. 39: 1437-1442.

Nakaya HI, Amaral PP, Louro R, Lopes A, et al. (2007). Genome mapping and expression analyses of human intronic noncoding RNAs reveal tissue-specific patterns and enrichment in genes related to regulation of transcription. Genome Biol. 8: R43.

Razook AG, Figueiredo LA, Cyrillo JNSG, Pacola LJ, et al. (1997). Prova de ganho de peso: Normas adotadas pela Estação Experimental de Zootecnia de Sertãozinho. Boletim Técnico, n. 40. (In Portuguese) Instituto de Zootecnia, Nova Odessa.

Ropka-Molik K, Oczkowicz M, Piórkowska K, RóSycki M, et al. (2001). New polymorphisms and expression of the porcine ghrelin (GHRL) gene in different pig breeds. J. Anim. Feed Sci. 20: 186-199.

Sas Institute (2000). SAS User's Guide. SAS Institute Inc., Cary.

Sherman EL, Nkrumah JD, Murdoch BM, Li C, et al. (2007). Polymorphisms and haplotypes in the bovine neuropeptide Y, growth hormone receptor, ghrelin, insulin-like growth factor 2 , and uncoupling proteins 2 and 3 genes and their associations with measures of growth, performance, feed efficiency, and carcass merit in beef cattle. J. Anim. Sci. 86: 1-16.

St-Pierre DH, Wang $L$ and Taché $Y$ (2003). Ghrelin: a novel player in the gut - brain regulation of growth hormone and energy balance. News Physiol. Sci. 18: 242-246.

Sun J, Jin Q, Zhang C, Fang X, et al. (2011). Polymorphisms in the bovine ghrelin precursor (GHRL) and Syndecan-1 (SDC1) 
genes that are associated with growth traits in cattle. Mol. Biol. Rep. 38: 3153-3160.

Ukkola O and Pöykkö S (2002). Ghrelin, growth and obesity. Ann. Med. 34: 102-108.

Van Vleck LD, Pollak J and Oltenacu EAB (1987). Genetics for the animal sciences. W. H. Freeman and Company, New York. Wajnrajch MP, Ten IS, Gertner JM, Leibel R (2000). Genomic organization of the ghrelin gene. J. Endocr. Genet. 1: 231-233.

Walsh JB (1999). Mixed-model and bayesian analysis of shortterm selection experiments: 1999. Available at: [http://biosci. arizona.edu/zbook/volume_2/chapters/vol2_07.html.] Accessed July 1, 2014.

Wojtysiak D and Kaczor $U$ (2011). Effect of polymorphisms at the ghrelin gene locus on carcass, microstructure and physicochemical properties of longissimus lumborum muscle of Polish Landrace pigs. Meat Sci. 89: 514-518.

Zhang AL, Zhang L, Zhang LZ, Zhang CF, et al. (2012). Effects of ghrelin gene genotypes on the growth traits in Chinese cattle. Mol. Biol. Rep. 39: 6981-6986. 